\title{
Creating Social Value for the 'Base of the Pyramid': An Integrative Review and Research Agenda
}

\author{
Addisu A. Lashitew ${ }^{1} \cdot$ Somendra Narayan ${ }^{2} \cdot$ Eugenia Rosca $^{3} \cdot$ Lydia Bals $^{4,5,6}$
}

Received: 23 July 2019 / Accepted: 16 December 2020 / Published online: 7 January 2021

(c) The Author(s) 2021

\begin{abstract}
A growing body of research looks into business-led efforts to create social value by improving the socio-economic wellbeing of Base of the Pyramid (BoP) communities. Research shows that businesses that pursue these strategies—or BoP businesses-face distinct sets of challenges that require unique capabilities. There is, however, limited effort to synthesize current evidence on the mechanisms through which these businesses create social value. We systematically review the literature on BoP businesses, covering 110 studies published in business and management journals. We start by using bibliographic analysis to map the broad contours of the literature in terms of its common theoretical and empirical approaches, intellectual core, and evolution in time. We subsequently conduct a qualitative content analysis on the identified articles to synthesize their main findings. The analysis leads to a conceptual framework that explicates the antecedents, constraints, capabilities, and contingencies that drive social value creation. In addition to providing a rich and systematically organized account of the evidence, our analysis provides a critical reflection on the ethical dilemmas of social value creation efforts for the BoP, and outlines promising avenues for future research.
\end{abstract}

Keywords Base of the pyramid $(\mathrm{BoP}) \cdot$ Social value $\cdot$ Ethical dilemmas $\cdot$ Systematic review

\section{Introduction}

For nearly two decades, business researchers and practitioners have explored the potential contributions of multinationals and local businesses towards poverty alleviation in lowerincome markets (Prahalad and Hammond 2002; Prahalad 2004; Kolk et al. 2014). These approaches are underpinned by the notion that businesses can concomitantly advance their competitiveness by improving the social well-being of disadvantaged communities (Prahalad 2004). These businesses seek to reduce inequalities by creating solutions that empower base of the pyramid (BoP) communities, which include large segments of society at the lower rungs of the socio-economic pyramid with vulnerable livelihoods that are often centered on informal activities (London et al. 2010; Hammond et al. 2007; Prahalad 2004). Current research on businesses that pursue these strategies-or BoP businesses-has pointed to the significant challenges of simultaneously creating social value and financial return (Kolk et al. 2014). Business strategies that aim to create social value often fall short of their ambitions (Dembek et al. 2019), or worse, end up creating unintended negative outcomes such as crime and social exclusion (Hall et al. 2012). 
This burgeoning literature has started to shed light on the capabilities, strategies, and boundary conditions that influence social value creation in developing economies (Hart and London 2005). Recent evidence highlights the contingent nature of social value creation for the BoP, whereby various elements of the business model interact with external conditions in influencing performance (Kolk et al. 2014). There has been, however, limited integrative analysis that synthesizes current evidence on the mechanisms of social value creation. Acquiring fine-grained understanding of social value creation processes will, in return, necessitate greater clarity in key concepts and elements of the research design, including the features of business models, their internal mechanisms, and features of the business context (Dembek et al. 2016; Kolk et al. 2014).

This study aims to synthesize current evidence on the complex dynamics of social value creation for and with BoP communities. We systematically review 110 articles that were published until early 2018 with the aim of providing a coherent and in-depth understanding of social value creation processes. Unlike other recent reviews, particularly Dembek et al. (2019) and Kolk et al. (2014), that provided an overview of the research field, this study offers an indepth account of the evidence that outlines key assumptions, processes, and outcomes. The review is thus guided by the following research question: What are the mechanisms of social value creation in BoP businesses, and how do they influence social value creation outcomes?

We use the results of the analysis to develop an integrative framework of social value creation in BoP businesses that depicts their antecedents, the constraints they face, the capabilities they deploy, their performance, and the contingencies that influence them. The framework captures the dynamic interplay between internal business features and external conditions in influencing social value creation. Our critical analysis sheds light on the ethical dilemmas that arise in BoP businesses, and reveals how social value creation is a contested domain of praxis that is a staging ground of competing ethical views (Osorio-Vega 2019; Dembek et al. 2019). We have built on the analysis to outline a research agenda that can move the literature forward. Together, these contributions have the potential to help streamline the discourse and facilitate interaction among the various research streams that look into social value creation.

The rest of the paper is organized as follows. Section two sets the stage by sketching the broad outlines of the literature, and section three outlines our methodology for selecting articles and data analysis. Section four presents bibliographic analysis results that portray the theoretical roots, methodological orientations, and other features of the literature. Section five presents the results of the qualitative content analysis that lead to an integrative framework of social value creation. Section six concludes the paper by discussing our main results and outlining an agenda for future research.

\section{Background Literature}

The literature on BoP businesses has long explored how businesses can advance poverty alleviation and social inclusion in lower-income economies (Prahalad 2004; Kolk et al. 2014; Dembek et al. 2019). The call for multinational enterprises (MNEs) and other businesses to take up poverty alleviation as part of their core business strategies (Prahalad and Hammond 2002; Prahalad and Hart 2002) was motivated by the view that philanthropic initiatives of corporate social responsibility (CSR) have failed to make a dent in global poverty. These new approaches sought to advance a more strategic orientation towards poverty alleviation by treating social and environmental issues as sources of competitiveness (Williams and Hayes 2013; Arnold and Valentin 2013). The early literature attempted to demonstrate the untapped market potential of the BoP market segment, and emphasized the need to devise novel value offerings that meet their unique requirements (Prahalad 2004). This approach, also called BoP 1.0, has been subjected to critiques for ignoring the fundamental development needs of the poor and overstating their purchasing power (Karnani 2007). Researchers have questioned the value of BoP strategies, arguing that BoP businesses seek to "commercialize" poverty only to enrich multibillion-dollar corporations (Dembek et al. 2019; Karnani 2007). This has sharpened attention to ethical dilemmas related to the appropriateness of products, fair pricing, advertising, distribution, and packaging concerns (Davidson 2009). A genuine effort to reduce poverty, it was argued, required more sustained interventions to increase the incomes of the poor by improving their employment opportunities, productivity, and market access (Karnani 2007). This has led to the emergence of a new approach called BoP 2.0, which emphasizes the need to develop unique competences to overcome the harsh economic realities of lowerincome communities, and to collaboratively "create fortune with the BoP" (Dembek et al. 2019; Hart et al. 2016; London and Hart 2011). Scholars have particularly underscored the need to build local capabilities by fostering deep engagement and cocreation with BoP communities (Nahi 2016; Simanis and Hart 2009; Dentoni et al. 2016).

The most recent iteration of the literature, BoP 3.0, advocates tailored strategies that include adopting a purposedriven mindset and leveraging interactive, open innovation systems to build collaborative business ecosystems (Caneque and Hart 2017). Studies also assert that business approaches should be accompanied by public policy efforts to address ethical challenges by creating a fair market environment and removing affordability constraints (Aiyar and Venugopal 
Table 1 Core studies in the research stream: top 10 most cited articles

\begin{tabular}{llll}
\hline & Author(s) & Source of publication & $\begin{array}{l}\text { Total citations } \\
\text { (as of July } \\
2020)\end{array}$ \\
\hline 1 & London and Hart (2004) & Journal of International Business Studies & 634 \\
2 & Mair and Marti (2009) & Journal of Business Venturing & 457 \\
3 & Yunus et al. (2010) & Long Range Planning & 391 \\
4 & Karnani (2007) & California Management Review & 358 \\
5 & Mair et al. (2012) & Academy of Management Journal & 351 \\
6 & Seelos and Mair (2007) & Academy of Management Perspectives & 292 \\
7 & George et al. (2012) & Journal of Management Studies & 219 \\
8 & Prahalad (2012) & Journal of Product Innovation Management & 202 \\
9 & London et al. (2010) & Journal of Business Research & 166 \\
10 & Matos and Silvestre (2013) & Journal of Cleaner Production & 118 \\
\hline
\end{tabular}

These citation counts were based on a search at the ISI Web of Science database on July 1, 2020
2019). Business ethics scholars have subsequently proposed an integrative justice model that outlines the conditions needed to create fairness for BoP communities through non-exploitative intent, cocreation, long-term orientation, and stakeholder interest representation (Santos et al. 2015). These developments have sharpened the scope and depth of the literature by bringing attention to the various organizational and managerial processes of social value creation. Nonetheless, cumulative knowledge does not appear to have been accompanied by performance improvements, as recent research has questioned the efficacy and ethical foundations of BoP businesses in advancing poverty alleviation. At best, business-led initiatives for poverty alleviation have had mixed success (Kolk et al. 2014), or in some cases have created unexpected negative externalities (Hall et al. 2012).

The goal of this research is to shed light on social value creation processes and outcomes, and the ethical dilemmas inherent to them through an integrative review of the literature. In trying to analyze social value creation by BoP businesses, we adopt a working definition that lays out the scope and context of our analysis. Building on previous studies (see Table A1 in the Appendix), we define social value creation as business-led approaches for improving the socio-economic well-being of BoP communities in an economically viable manner. This definition is based on other studies in the literature, such as Sinkovics et al. (2014), but does not specify the complex, normatively laden concept of social development and well-being. It is, however, specific enough to guide our analysis of social value creation in BoP businesses. The focus on economic viability differentiates social value by BoP businesses from other forms of social impact created by publicly funded development programs or non-governmental organizations. Economic viability implies the presence of a self-sustaining mechanism for improving socio-economic well-being of BoP communities, without a recourse to public or philanthropic funds. For businesses, it also indicates the possibility that they can address social issues while at the same time covering their expenses and/ or receiving some level of return on their financial investments. Following this definition, BoP communities (or simply the BoP) are the targeted stakeholders or beneficiaries; BoP businesses are the actors; social value creation is the process; and social value is the outcome for BoP communities and other stakeholders.

Finally, ethical considerations are integral to various aspects of social value creation for the BoP, which makes them an important part of our analysis. The next section will outline the steps we followed for selecting articles and conducting our review.

\section{Methodology}

We combine content analysis and bibliographic analysis to distill current evidence on the mechanisms of social value creation for BoP communities. Figure 1 summarizes the five stages we followed for the analysis. In the first stage, we developed a review protocol in accordance with the standard review practice in the wider field of management research (e.g., Haffar and Searcy 2017; Kolk et al. 2014). We identified the articles for our review using a selection approach that combines two categories of keywords (see Fig. 1), which is in line with the central tenets of systematic literature reviews (Tranfield et al. 2003). The full list of keywords used for article selection is shown in Fig. 1, the subsequent article filtering process can be found in the Appendix (Fig. A2).

The second stage involved applying a number of additional selection criteria to enhance the validity and reliability of the article selection process. This helped us identify new articles that did not make their way into our sample inter alia because they did not use our keywords in their abstracts 


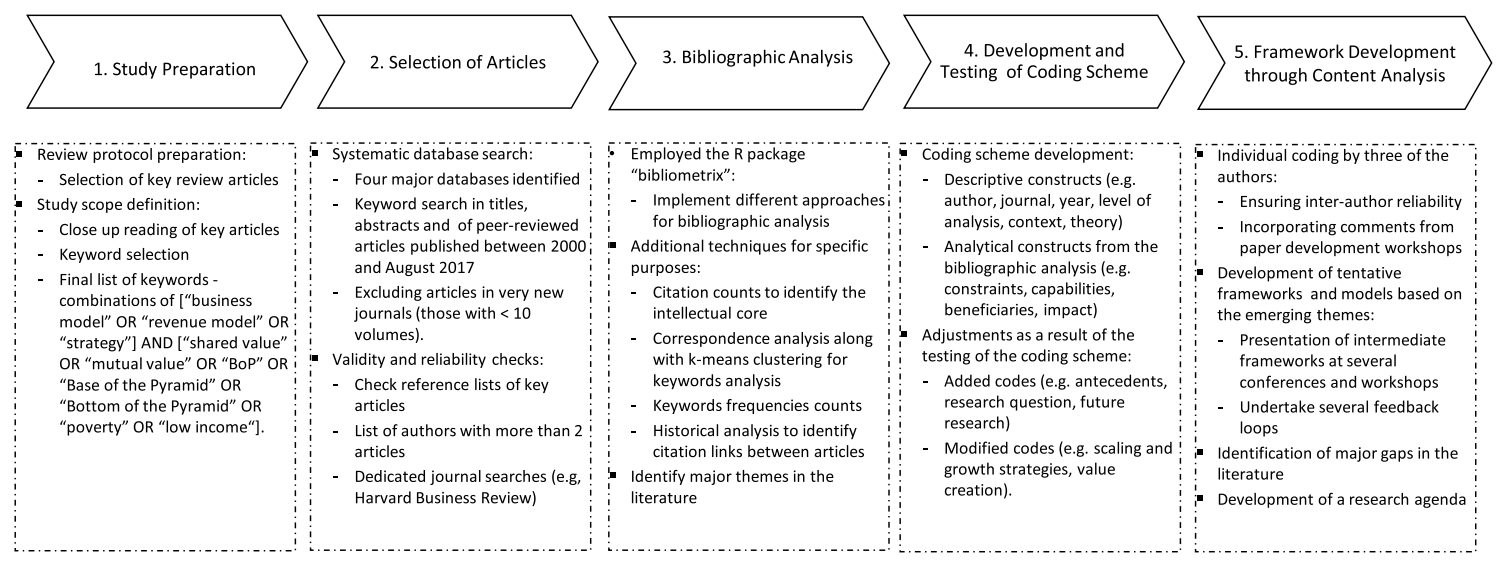

Fig. 1 Overview of the research stages

(e.g., Kolk et al. 2014; Tate and Bals 2018). In the third stage, a bibliographic analysis was conducted to systematically map the underlying structure and intellectual core of the literature (Di Stefano et al. 2010). By taking publications as the unit of analysis, bibliographic analysis helps summarize the development and intellectual foundations of a research stream. Following Di Stefano et al. (2010), we conducted both citation and co-citation analysis to map key influences in the development of the research stream as well as relationships between different schools of thought.

In the fourth stage, we used insights from the bibliographic analysis to develop a coding scheme for in-depth content analysis on the identified articles. The coding scheme included both descriptive and analytical constructs, which enabled the development of both quantitative and qualitative insights (Haffar and Searcy 2017). Appendix A3 shows an extract of the coding scheme with an example of a coded article. The fifth, final stage of our analysis involved the development of an integrative framework based on the results from the bibliometric analysis and qualitative content analysis. Standard procedures for thematic analysis (Braun and Clarke 2006) were employed for identifying the aggregate concepts that constitute the core elements of our social value creation framework (e.g., keyword frequencies in the abstracts, summarized in A8; categories of organizational capabilities crucial for social value creation, summarized in Table 2). The preliminary results, including an early version of our integrative framework, were presented at a paper development workshop attended by leading researchers in business ethics, sustainability, and BoP communities. We iteratively revised our coding scheme and subsequent results based on feedback from the workshop and emerging insights from our data analysis. The Appendix provides figures that characterize the coded articles in terms of journal outlets, theoretical perspectives, methodologies, and thematic focus (see Figs. A4, A5, A6, and A7 in the Appendix). The full sample of 110 articles is presented in Table A10 in the Appendix.

\section{Bibliographic Analysis}

\section{Citation Analysis to Identify the Intellectual Core}

Since citation counts are considered important measures of intellectual influence, their analysis can lay out underlying patterns in the theoretical structure of a stream of literature (Di Stefano et al. 2010). We conduct citation analysis by mapping the citation counts of articles in our sample that were listed on the ISI Web of Science database (a final set of 77 articles). Among these studies, the average number of citations was 52.05. A subtotal of 20 articles had more than that average number of citations, constituting $78.99 \%$ of the total (Table 1).

\section{Co-citation and Keyword Analysis to Identify Major Themes}

We conducted two types of bibliographic network analyses to identify underlying research themes in the literature. Both were implemented using the R package-Bibliometrix. First, we used co-citation analysis to identify instances of two articles in our sample citing a common third article (including studies beyond our sample). This method is useful for tracing the theoretical roots underpinning the research field. We use the Jaccard index ${ }^{1}$ to calculate a relative measure of bibliographic co-occurrence that captures the degree of overlap

\footnotetext{
1 The Jaccard index is calculated as the ratio between the intersection and the union of the citation sets of any two studies. The index is considered a superior measure of co-citation relative to other measures due to its ability to avoid spurious correlations in the co-occurrence matrix (Leydesdorf 2008).
} 


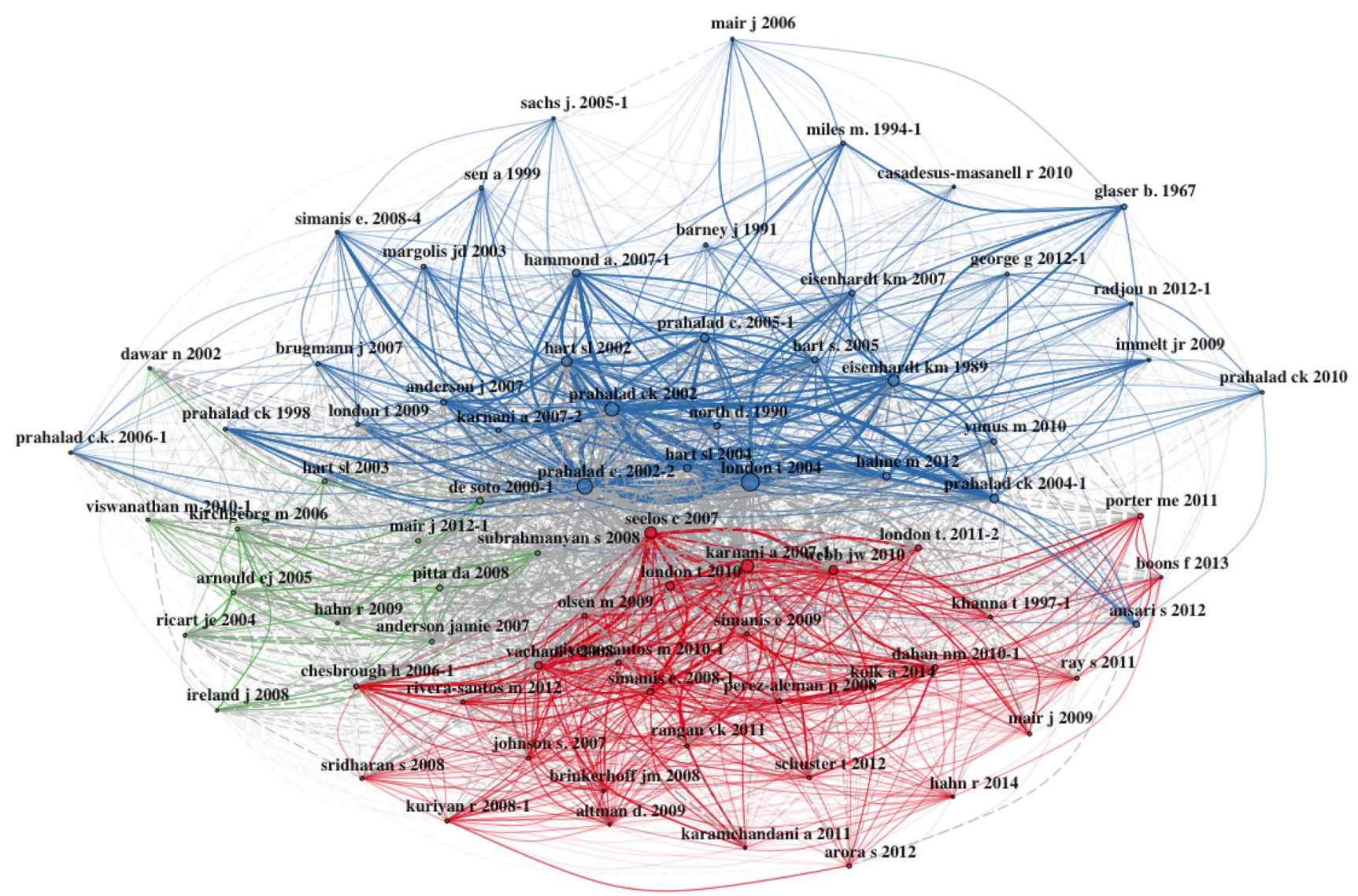

Fig. 2 Common scientific underpinnings of the literature-article co-citation network using Jaccard similarity coefficient

between sets of cited references from each article in our sample. Further, we use the Fruchterman-Reingold layout to plot the most salient references cited by the articles in our sample (Fruchterman and Reingold 1991), and subsequently visualize the clusters of scientific sources underpinning the literature (see Fig. 2). The network plot reveals three key cocited clusters of sources in the background literature.

Primarily, we find that BoP research builds on the broader literature on social entrepreneurship and social impact (Sen, 1999; Mair and Marti 2006; Siemanis 2008, Yunus et al. 2010) for conceptualizing key concepts and theory building (North, 1990; Eisenhardt and Graebner 2007). Second, BoP research draws heavily on the literature in the fields of business models (Chesbrough et al. 2006; Seelos and Mair 2007; Arora and Kazmi 2012), and organizational processes and capabilities (Olsen and Boxenbaum 2009; Ansari et al. 2012). Further, a large section of the literature addresses value creation for the BoP by building on the fields of marketing (Ireland 2008; Pitta, Guesalaga, and Marshall 2008) to discuss market development for the BoP. Finally, studies like Prahalad (2004), London and Hart (2004), Prahalad and Hart (2002), and Prahalad Hammond (2002) serve as common threads linking these various streams of literature.
We subsequently conducted an abstract-based keyword co-occurrence analysis to map major themes in the literature ( $c f$. Di Stefano et al. 2010). Keywords from the abstracts were used to conduct multiple correspondence analysis and hierarchical clustering, which was then depicted by a dendrogram plot illustrating key conceptual clusters. The dendrogram plot in Fig. 3 reveals four major themes, each a subset of the previous one. The first three are higher level aggregates pertaining to (i) sustainable business models for low-income communities; (ii) business models for inclusive societies; and (iii) local impact through capability development and institutional change. The final cluster at the lower end of the dendrogram indicates the various elements of inclusive business models for social value creation. The top half of this cluster captures the managerial challenges of multinational businesses, including developing a proper understanding of local markets. The bottom half of this cluster is related to the various elements and processes of social value creation such as market development, devising the appropriate organizational processes, and local (institutional and market) challenges and contingencies that influence value creation for local communities. A closeup analysis based on the frequency of keywords in the abstract 
Table 2 Types of organizational capabilities

\begin{tabular}{ll}
\hline Organizational capabilities for BoP business models & \\
\hline Organizational ambidexterity & Managing a mix of projects with multiple goals \\
& Managing diverse stakeholder interests \\
Cross-cultural knowledge \& sensitivity \\
Leveraging technology & Identifying and working with external stakeholders \\
& Appropriate and affordable value offerings \\
& Overcoming distribution challenges \\
& Devising novel business models \\
Partnerships and cocreation & Increasing reach and scale \\
& As an end-goal of intrinsic value \\
& As a means for developing new capabilities \\
& As a means for market access \\
Developing social capital & As a tool for orchestrating and legitimizing change \\
& As an end-goal of intrinsic value \\
Ecosystem building & As a means for resource and knowledge access \\
& As a means for governance \\
& Reforming systems of market coordination \\
& Strengthening value chains \\
& Developing government capacity \& transparency
\end{tabular}

further confirms the focus on capabilities, contingencies, constraints, and outcomes. It also unravels the wide group of involved stakeholders, namely multinationals, entrepreneurs, communities, and BoP consumers and producers (see Table A8). In sum, the bibliographic analysis revealed that the debate in the literature is centered on building capabilities to overcome the constraints and contingencies of social value creation for and with BoP communities.

\section{Historical Citation Analysis of Field Development}

We subsequently conducted historical citation analysis to understand the evolution of the research stream. We use a historiographic approach and develop a chronological network map of the most relevant direct citations using data of direct in-group citations (Fig. 4).

The historical citation analysis in Fig. 4 identifies three important phases that characterize the different stages of development of the literature. Stage I (2002-2006) entails a clear business-centric focus on market access, and consists in several articles addressing specific elements of BoP business models. London and Hart (2004), for example, pioneered the view that MNEs need to adopt different strategies for entering low-income economies. During the second stage (2006-2008), several key articles built on London and Hart (2004) by emphasizing the importance of new capabilities for BoP businesses-such as technological capabilities (Chesbrough et al. 2006), and partnerships with NGOs and distribution channels (Vachani and Smith 2008; Perez-Aleman and Sandilands 2008). This period also saw the emergence of important debates on the various ethical dilemmas, scaling challenges, and managerial complexity associated with BoP businesses (Karnani 2007; Seelos and Mair 2007). The discussion also ignited an important debate on the question of how BoP businesses should organize themselves, specifically contrasting adapting current business models against designing new ones (Vachani and Smith 2008; Seelos and Mair 2007). The third and final stage (2008-2017) was a period of high productivity, and saw the proliferation of the literature into multiple domains. Subsequent research covered issues such as internal organizational contingencies that constrain inclusive innovations (Halme et al. 2012; George et al. 2012) and external institutional contingencies (Mair and Marti 2009). This stage also witnessed a shift of emphasis from the original "doing well by doing good" perspective of Prahalad (2004), towards the perspective of ecosystem building and cocreating social value (Simanis and Hart 2009; Porter and Kramer 2011). This demonstrates a shift of emphasis from selling to the poor (BoP 1.0), to cocreating new solutions with local communities (BoP 2.0) to simultaneously advance social, economic, and sustainability outcomes.

\section{An Integrative Framework of Social Value Creation}

The bibliographic analysis has revealed the growing complexity of the literature on BoP businesses. To better shed light on the specific mechanisms of social value creation, we have developed an integrative social value creation framework, which is depicted in Fig. 5. The framework builds on the themes that emerged from the bibliographic analysis (e.g., as indicated by the keyword frequencies in the abstracts, summarized in A8), and integrates them with detailed analysis of the literature through a qualitative content analysis (e.g., categories of organizational capabilities crucial for social value creation, summarized in Table 2), 


\section{Height}

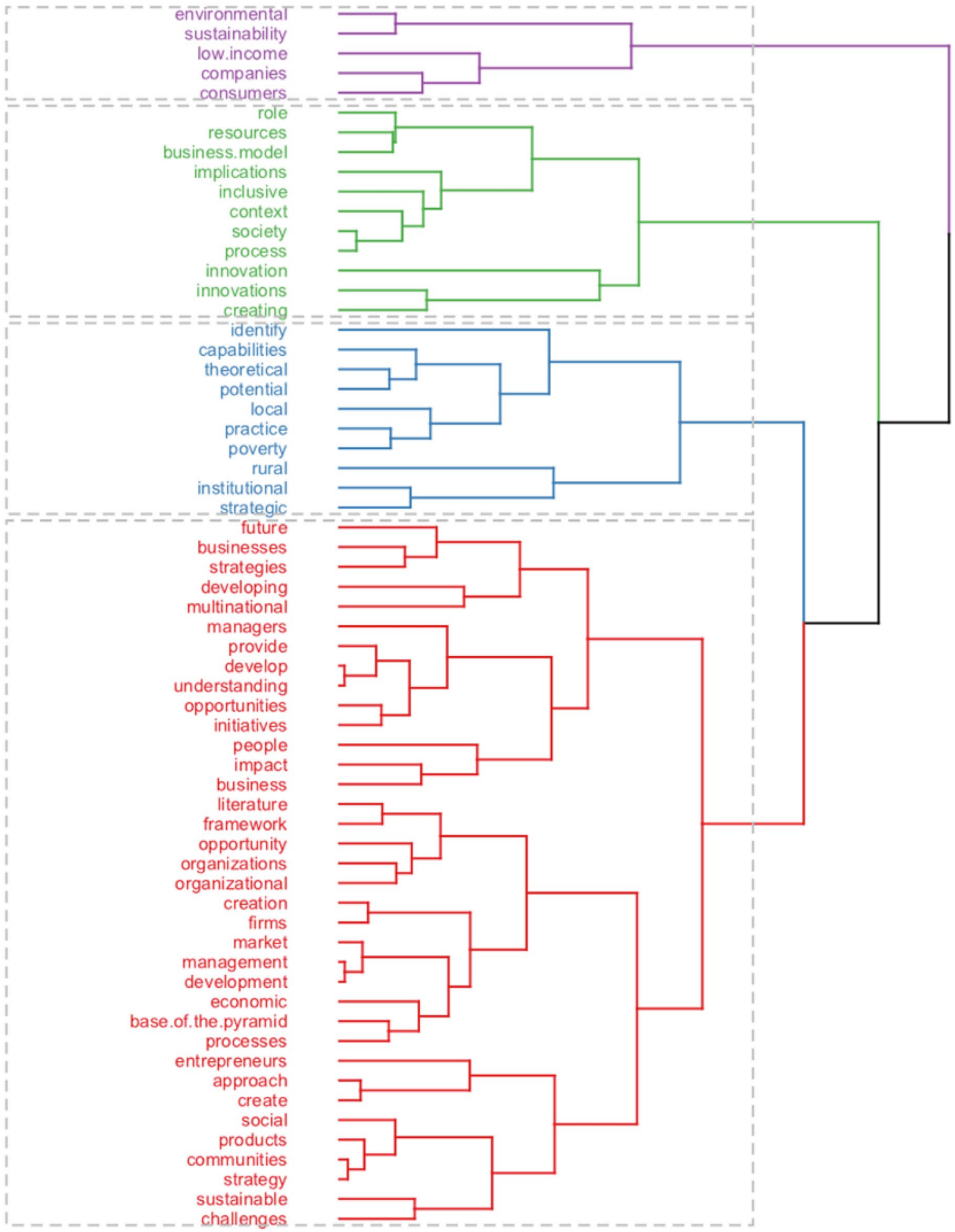

Fig. 3 A hierarchical dendrogram depicting major conceptual clusters in the literature. The height indicates the distance metric between clusters. The shorter the height, the closer the similarity between keyword clusters 


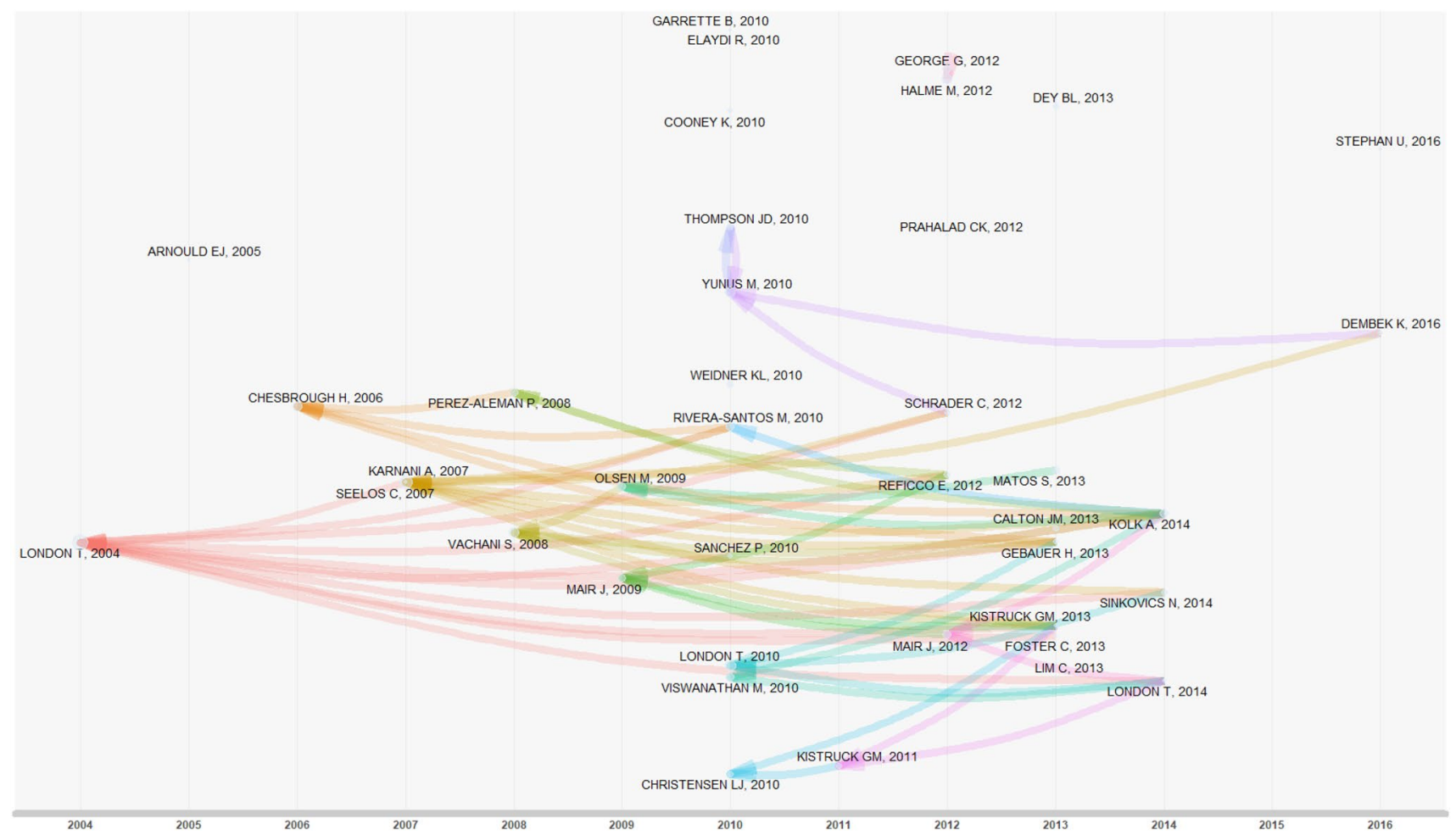

Fig. 4 Historical direct citation network for $>20$ citations (top half of the sample)

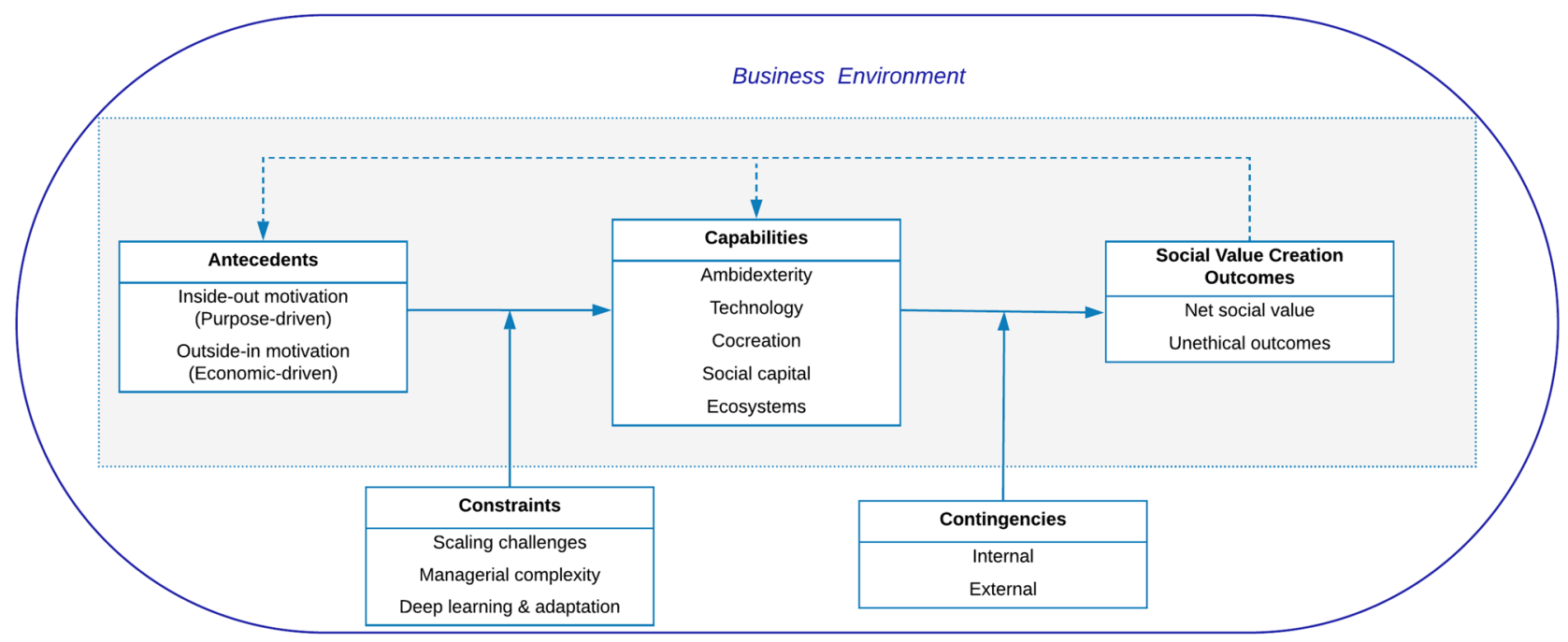

Note: The shaded area of the figure indicates elements of the business model that are amenable to direct managerial influence.

Fig. 5 A framework of social value creation in BoP businesses. The shaded area of the figure indicates elements of the business model that are amenable to direct managerial influence

which involved careful coding of key themes as described in the methodology. The shaded panel of the Fig. 5 delineates the internal elements of BoP business models-antecedents, capabilities, and outcomes - that are comparatively more amenable to direct managerial control. The other two elements are constraints and contingencies that are largely 
exogenous and thus beyond immediate managerial discretion. This section discusses each of these components of the framework; Table A9 in the Appendix provides examples of studies in our sample that address each specific element of our framework.

\section{Antecedents}

We identify two motivational antecedents for BoP businesses. The first antecedent is what we call "outside-in motivation", or the economic-driven interest to create social value as a means of advancing financial competitiveness. This includes the desire to exploit the untapped market potential of the BoP market segment (Prahalad 2004), or to ensure an efficient and sustainable supply chain, as in the case of Starbuck's development programs that target smallholder coffee farmers (Perez-Aleman and Sandilands 2008). Multinationals and other companies that are motivated by economic causes first consider the commercial value of the BoP market segment before turning inwards to devise strategies for creating impact (Seelos and Mair 2007).

The second antecedent of BoP businesses is "inside-out motivation", whereby organizations design their internal goals and processes from the outset with the aim of creating social value. This approach is widespread among social enterprises and "born BoP" businesses whose strategic priority is advancing social value (Yunus et al. 2010; Hart et al. 2016). Tate and Bals (2018), for example, discuss how three social businesses help revive the local communities in disaster-afflicted Haiti by developing social resources and capabilities. George et al. (2015) describe a public-private partnership that introduced affordable emergency healthcare solutions to the rural and urban poor in India.

While economic motivations are predominant among large corporations, purpose-driven approaches tend to be grassroots-based, and motivated by the personal desires of entrepreneurs to remove key constraints in their local environments (Hart et al. 2016; Seelos and Mair 2005). The foundations for inside-out motivations can be related to normative considerations or problem-solving capabilities. Social entrepreneurs are often driven to set up ventures by their aspiration to exploit their technical and business skills towards resolving "trigger constraints" that debilitate their environments (Sinkovics et al. 2014; George et al. 2015). In other cases, the cognitive and affective attributes of individuals inspire them to establish BoP businesses. Motivational attributes related to empathy (i.e., the emotional recognition of others' needs) and moral judgment (i.e., the desire to "do the right thing") often influence the perceived desirability of setting up social ventures among prospective entrepreneurs (Mair and Noboa 2006: 128). Prosocial values of top managers could also provide standards of conduct that propel them to champion business-led approaches to advance social value.

The two motivations, however, do not necessarily arise in isolation, and can interact with each other in driving social value creation strategies. The broader literature on organizational change suggests that the co-existence of economic and normative (cause-driven) motives can facilitate transformative organizational change. Hahn et al. (2016), for example, argue that ambidextrously balancing between instrumental and normative prescriptions for social engagement can lead to greater social performance as it extends the scope and scale of social initiatives. The extent to which economic and normative motives can co-exist and complement each other can thus be important in determining social value creation processes and outcomes.

\section{Constraints}

The business environment in lower-income countries is pervaded by "institutional voids" that pose significant growth barriers but also provide potential market opportunities (Mair et al. 2012). Our analysis identified three broad categories of constraints that encumber businesses that serve BoP communities, as summarized in Fig. 6. These constraints are related to market conditions, (formal) regulatory institutions, and (informal) socio-cultural institutions. A large number of studies have provided an extensive coverage of the constraints arising from the external environment, including Mair et al. (2012), Rivera-Santos and Rufín (2010), London et al. (2010), and Parmigiani and Rivera-Santos (2015). Considering that previous research has addressed the nature of these constraints in great detail (Halme et al. 2012), we will focus on three important implications of these constraints for BoP businesses, namely, managerial complexity, scaling challenges, and the need for deep learning and adaptation.

\section{Scaling Challenges}

The extent to which BoP ventures meet their goal of advancing social value depends on their ability to scale up their operations (Prahalad 2004). Scaling is an important means of growth because of the market characteristics of the BoP socio-economic segment, particularly the high price sensitivity of low-income customers, which leaves limited room for growth strategies that involve differentiation based on quality (London et al. 2014). High operating costs in lowerincome markets further put a dent on their profit margin, while the resource-intensive and lengthy process of developing markets increases total investment outlays (Simanis and Hart 2009). Scaling is also complicated by the small size, or "thinness", of individual markets, which makes it necessary to replicate operations in multiple, often heterogeneous, 


\begin{tabular}{|c|c|c|}
\hline Market constraints & Regulatory constraints & Socio-cultural constraints \\
\hline $\begin{array}{l}\text { Inefficient capital markets } \\
\text { Infrastructure gaps } \\
\text { Low access to technology } \\
\text { Lack of educated labor force } \\
\text { Lack of intermediate services } \\
\text { (e.g. market research \& logistics) } \\
\text { Low purchasing power } \\
\text { Resource scarcity } \\
\text { Thin (small) market size } \\
\text { Informal economy }\end{array}$ & $\begin{array}{l}\text { Inefficient economic institutions } \\
\text { (e.g. property rights) } \\
\text { Inefficient regulatory institutions } \\
\text { (e.g. tax laws) } \\
\text { Regulatory uncertainty } \\
\text { Inefficient public service (e.g. } \\
\text { red-tape and corruption) } \\
\text { High information asymmetry } \\
\text { High agency cost }\end{array}$ & $\begin{array}{l}\text { High bonding social capital } \\
\text { Low bridging social capital } \\
\text { Limited trust in institutions } \\
\text { Informal relationships } \\
\text { Reliance on social or implicit } \\
\text { contracts } \\
\text { Tensions between different } \\
\text { stakeholders } \\
\text { High cultural heterogeneity }\end{array}$ \\
\hline \multicolumn{3}{|c|}{ Implications for social value creation } \\
\hline
\end{tabular}

Fig. 6 Major constraints for social value creation and their organizational implications

low-income contexts (Prahalad 2004). Social ties and other capabilities needed to create contextualized solutions are also often non-transferable (Hillemann and Verbeke 2014), leading to duplicate efforts to develop capabilities in every market the firm enters that increase costs and limit scaling (Reficco and Márquez 2012).

Scaling strategies such as franchising are limited by institutional constraints such as low intellectual property protection, high information asymmetries, and significant agency costs, which increase the risk of opportunism (Vachani and Smith 2008). The absence of formal distributional channels also makes it necessary to develop a locally embedded distribution and supply chain network (Bendul et al. 2017). A common example is Hindustan Unilever's direct-to-consumer retail distribution initiative that uses "village ladies" to reach rural consumers. Given the limited availability of formal marketing channels, BoP businesses often have to develop non-traditional and costly marketing approaches such as word-of-mouth marketing, and direct marketing through road shows and workshops (Beninger and Robso 2015). These challenges indicate why relatively few BoP businesses have managed to scale up their operations to achieve their full potential of creating social value (Garrette and Karnani 2010).

\section{Managerial Complexity}

Institutional constraints in the lower-income contexts force managers to expend significant effort to build alternative governance mechanisms that rely on informal networks and reciprocity (Rivera-Santos and Rufín 2010). This creates a fuzzy boundary between the firm and its environment, exposing managers to complex demands related to social rules, norms, and cultural scripts (Mair and Marti 2006). The fluidity of institutional structures also makes it necessary to negotiate and creatively redefine external institutional arrangements (Mair et al. 2012). This includes devising novel governance processes through social control mechanisms or alternative goal structures (Kistruck et al. 2016), which could require a firm understanding of the institutional context, and active ties with strategic actors (Reficco and Márquez 2012). High market heterogeneity and strong informal ties create challenges in understanding complex patterns in consumer behavior, while also raising the need for cultural sensitivity in marketing, employment policies, and community engagement (Mair and Marti 2009; Kelly et al. 2010).

The presence of both pragmatic and normative consideration in business could also demand greater ethical awareness and creativity, or "moral imagination" to formulate new mental models for value cocreation (Calton et al. 2013). Managers will need the capability to go through multiple learning loops of "value engineering" (Gollakota et al. 2010) to devise value offerings that are commercially and socially viable (Reficco and Gutiérrez 2016). This can be a daunting demand if managers are unconvinced of the need or the plausibility of creating social value, leading to a mentality of trade-offs that deters them from identifying 
complementarities (Olsen and Boxenbaum 2009). Cognitive barriers are predominant in part because mainstream business education does not equip future managers with strategies for creating social value (Hart et al. 2016; London et al. 2010). In commercial enterprises, the motive of creating social value could collide with established organizational practices such as project evaluation criteria that prioritize short-term financial performance and minimize external risk, incentive structures that reward operational efficiency, and rigid organizational practices that inhibit cocreation (Olsen and Boxenbaum 2009). Among enterprises that have a history of working as non-profit organizations, Kistruck and Beamish (2010) find that engagement in social entrepreneurship was constrained by cognitive, cultural and network embeddedness. These interlocking cognitive, procedural and structural barriers will impose severe organizational and managerial constraints that undermine social value creation processes.

\section{Deep Learning and Adaptation}

The poor development of market institutions in low-income economies means that BoP businesses in these economies have limited market information, which exposes them to significant uncertainties. High uncertainty is compounded by the complex and interdependent nature of social issues, making it very difficult to anticipate future challenges and formulate informed strategies (Sinkovics et al. 2014; Yunus et al. 2010). The large number of contingencies deny managers a structured decision environment, forcing them to use rules-of-thumb and heuristics for decision making (Thompson and MacMillan 2010). Managing BoP businesses thus becomes a process of discovery, involving learning-by-doing and iterative adaptation and reformulation of various components of the business model (Duke 2016). These challenges have given rise to a strong emphasis on the need for carefully designed and lengthy pilots, and starting small-scale experimental ventures (Yunus et al. 2010).

The need for deep learning and significant adaptation makes it necessary to design modular, flexible, and scalable business models (Angeli and Jaiswal 2016). Researchers emphasize the need for developing new capabilities through an immersive process of cocreation that integrates local knowledge in product and business model design (Nahi 2016). Many MNEs, however, settle for "quick fixes" through a minor adaptation of their existing business models from developed markets that have dramatically different institutional and market features (Garrette and Karnani 2010). MNEs are thus advised to actively "un-learn" their existing capabilities (Prahalad 2012) and develop new organizational mindsets and attitudes that pay greater attention to the specificity of local contexts (London and Jäger 2019). This requires a growth strategy that focuses on market-building, and fine-tuning business operations before aiming to scale. However, a gradual approach could be unfeasible in many businesses that face high operating costs, creating a major dilemma with respect to the pathways for growth (Goyal et al. 2015).

\section{Organizational Capabilities}

Researchers argue that the unique challenge of designing and executing $\mathrm{BoP}$ businesses requires a distinct set of managerial and organizational capabilities (Seelos and Mair 2007). Our content analysis identified five broad categories of organizational capabilities that are crucial for social value creation, which will be discussed in the remainder of this subsection (see Table 2).

\section{Organizational Ambidexterity}

Organizational ambidexterity refers to the ability to combine business processes underpinned by interrelated but distinct end-goals, logics, and time horizons (Reficco and Márquez 2012). The concept is highly relevant for understanding the process of social value creation, which involves significant elements of organizational learning, adaptation, and intensive external collaboration (Halme et al. 2012). The novelty and equivocality of social issues and their departure from established organizational practices compound the organizational challenges of identifying means and ends for creating social value for the BoP. Ambidextrous businesses can successfully mitigate potential trade-offs and risks among multiple projects with different end-goals and time horizons, divergent values and courses of action, and conflicting stakeholder interests (Van der Byl and Slawinski 2015).

Organizational ambidexterity relies on highly flexible managerial skills to devise the appropriate organizational designs through structures and processes that foster synergies and reduce frictions among social and financial goals (Hahn et al. 2016). Ambidextrous managers will also successfully forge and maintain relationships with diverse stakeholders and strategic partners (Hart et al. 2016). Due to the complexity of social value creation processes, BoP businesses have to deal with a diverse pool of stakeholders with potentially conflicting demands. For example, the expectations of parent (funding) companies might not be necessarily aligned with the strategic demands of the market environment (Duke 2016). Managers will thus have to attract likeminded partners who share their values, and seek to align and manage expectations at all times (Reficco and Márquez 2012). Ambidextrous managers can also successfully maintain an open organizational boundary to facilitate resource flow, while avoiding excessive or unreliable dependence on external actors (Duke 2016). Moreover, ambidexterity helps managers to bridge cultural gaps by understanding and 
mediating different cultural scripts and norms, which tend to be highly diverse in lower-income markets (Reficco and Márquez 2012).

\section{Leveraging Technology}

BoP businesses use technological advances to overcome market barriers, such as the high cost of creating and delivering value for BoP consumers (Prahalad and Hart 2002; Prahalad 2004). ICT and other new technologies enable disruptive innovations that dramatically increase the affordability and accessibility of fundamental products and services, thus facilitating low-margin, mass-market strategies. BoP businesses have exploited the ever-growing access to the internet and mobile phones to create novel organizational forms that achieved greater efficiency and capacity to scale (Chesbrough et al. 2006). For example, technologies such as mobile and internet payment have been used to create distribution networks that overcome the last-mile challenge of reaching remote communities through affordable, pay-as-you-go payment systems (Barrie and Cruickshank 2017). The solar energy company M-Kopa, for example, enables households without access to electricity to own a solar energy kit through micro-credit. Customers pay a daily installment for their use through the mobile money system of M-Pesa, which is universally available in Kenya (Lashitew et al. 2018).

The unique markets and institutional settings of lowincome economies are said to provide an ideal setting for developing low-cost "disruptive innovations" that can have greater potential social value creation (Prahalad 2004; Hart et al. 2016). Radical innovations, however, could introduce the innovator's dilemma if businesses fear that innovating cheaper and simpler products could cannibalize existing successful innovations (Reficco and Gutiérrez 2016). The desire to maintain the cash-cow at the top of the pyramid can force MNEs to refrain from developing radical innovations that provide the same service at lower prices (Halme et al. 2012). Moreover, innovations for BoP consumers could create trade-offs between standardizing and customizing innovations, which are difficult to reconcile (Van den Waeyenberg and Hens 2008). While the distinct market needs of BoP consumers require context-specific and tailored innovations (Prahalad and Hammond 2002; Chliova and Ringov 2017), the need to achieve scale through a mass-market strategy demands more generic solutions. Achieving scale through radical innovations is thus constrained by the trade-off between customizing and standardizing innovations.

\section{Partnerships and Cocreation}

Researchers emphasize the need for partnerships and cocreation in BoP businesses, which is motivated by multiple grounds. The business model and (global) value chain perspectives emphasize that boundary-spanning approaches are needed to successfully create social value (Sánchez and Ricart 2010; Yunus et al. 2010). Due to the multi-dimensional nature of poverty, social issues are complex and thus difficult for individual actors to fully comprehend (Nahi 2016). Devising effective and locally owned social interventions thus requires wide and deep cocreation through inclusive processes of deep dialogue and direct relationships with local communities (Rahman et al. 2014).

Strategic perspectives such as strategic network theory, resource dependency theory, and the resource-based view underscore the need to rely on external resources for accessing resources that reside outside the firm's boundary (London and Hart 2004; Hart and London 2005). Creating and implementing successful social innovations require in-depth local knowledge, contacts, and resources (Prahalad 2012). Cocreation thus provides these firms with an opportunity for integrating their capabilities with the resources and capabilities of local firms and NGOs to improve their responsiveness to customer needs, and better understand market and institutional conditions (Calton et al. 2013; London and Jäger 2019).

The social resource-based view emphasizes that nurturing social relationships is a central element of $(\mathrm{BoP})$ businesses that aim to empower and benefit local stakeholders (Tate and Bals 2018; Ansari et al. 2012). For example, Tate and Bals (2018) report that mission-driven businesses actively develop social capabilities through express social commitment, consistency, and connections with stakeholders. Through their case study of CHIFA, they show how a mission-driven business that is deeply connected with its community funds a local school, thus engaging and empowering its customers, employees, and beneficiaries.

Finally, research into institutional entrepreneurship and systemic change emphasizes the importance of social resources for galvanizing collective action to successfully orchestrate and legitimize social change (Stephan et al. 2016). Collaborative approaches have the advantage of mobilizing a broad spectrum of resources and coordinating action among diverse actors, enabling systemic change that overcomes institutional and market barriers (Le Ber and Branzei 2010). George et al. (2015), for example, discuss how institutional entrepreneurs advanced emergency medical care in India by actively altering institutional norms through public-private partnerships. Ramus and Vaccaro (2017) discuss how active stakeholder engagement helped overcome mission-orientation in an Italian social enterprise.

\section{Developing Social Capital}

Organizational social capital is understood as the relational qualities of the organization's social ties, and has been 
identified as an important capability for addressing the market and institutional limitations of lower-income economies (Valente 2012). The quality and content of social ties, including relational attributes such as trust, reciprocity, status, and norms, are considered to be crucial for social value creation, which requires a deep understanding of complex social issues (Anderson and Billou 2007). In these contexts, BoP businesses, MNEs in particular, are advised to "go indigenous" and build "native capabilities" that enable them to effectively combine local and global knowledge and create solutions that are aligned with local market needs (Hart and London 2005).

Researchers have identified two broad categories of outcomes associated with social capital: resource access and governance. For BoP businesses, social capital can facilitate the exchange of resources through interpersonal ties, which are difficult to acquire through market exchanges (Mair and Marti 2009). Bridging ties that diversify the firm's network can provide access to unique tangible and intangible resources that would otherwise be out of the firm's reach because of structural holes related to institutional or geographic distance (Nahapiet and Ghoshal, 1998). This is likely to be paramount for MNEs, which need to overcome their "liability of foreignness" and "liability of outsidership" (Sinkovics et al. 2014).

Being embedded within organizational networks can also provide a means of governance by facilitating resource pooling, cooperation, and coordinated adaptation (Nahapiet and Ghoshal, 1998). Embeddedness in social structures can inhibit opportunistic behaviors, and foster the development of trust and reciprocity. The incentive to adhere to norms and build reputation reduces uncertainty, and enhances cooperation among network members (Rivera-Santos et al. 2012). Social standing and affiliation with social groups also signals status and reliability (Jack and Anderson 2002), providing a mechanism of legitimation in contexts characterized by institutional voids (London and Hart 2004; Mair et al. 2012). For example, Tate and Bals (2018) document how a group of entrepreneurs in post-crisis Haiti responded to the detrimental effects of providing free stoves, which led to significant environmental waste and drove local businesses out of the market. These problems were resolved when the entrepreneurs collaborated with the NGOs providing the donations to offer the stoves for an affordable price.

\section{Ecosystem Building}

Lower-income markets are characterized by poorly developed "framework conditions", such as public services and other support institutions, which expose the firm to productivity losses and remedial costs (Simanis and Hart 2009). The failure of early experiments has highlighted the need for market-building efforts, which requires coordination across the value chain to mobilize resources, knowhow and build a shared vision (Porter and Kramer 2011). Researchers have thus advocated for a shift of emphasis from standalone to ecosystem-based, integrated business models through greater partnerships with civil society and other indigenous stakeholders (Caneque and Hart 2017; Sanchez and Ricart 2010).

An important aspect of ecosystem building is strengthening governance institutions. Prahalad (2004) conceptualized development as a process of social transformation, and emphasized the need for changing governance structures. He underscored that businesses need to contribute towards building transaction governance capacity to make governments accountable, accessible, and transparent to citizens. Although current evidence on how this can be done is patchy, this often entails experimental institutional changes in areas such as value chain governance, quality standards, distribution design, and payment systems (Porter and Kramer 2011).

\section{Contingencies}

A number of complex contingencies wield positive or negative influence on the performance of BoP businesses, contributing to varying levels of success in creating social value. Our review identified a number of internal and external contingencies-i.e., conditions that are not amenable to immediate managerial control and thus are treated as given in the short-term.

\section{Internal Contingencies}

Structural factors related to firm characteristics such as size, ownership, and governance structures could have an important effect on social value creation processes and outcomes (Hart et al. 2016). Small ventures and social enterprise are constrained by their limited financial and organizational capabilities (Karnani 2007), while the "liability of foreignness" of MNEs hampers their ability to develop and implement successful social innovations (Hart et al. 2016). For example, MNEs could struggle to develop social capital due to their limited social ties and poor understanding of the cultural subtleties of the local market. Latent attitudinal constraints can be particularly hard to detect, such as the predominant view among MNE managers that new innovations and practices could be simply transferred to lower-income countries (London and Jäger 2019; Angeli and Jaiswal 2016). The ability of BoP businesses to bridge their core capabilities to meet the specific context of the BoP could thus be a crucial contingency for success (London and Hart 2011; Van den Waeyenberg and Hens 2008).

Another important internal condition that could determine the successful integration of social and commercial goals is 
the presence of a mission-driven organizational identity. ${ }^{2}$ A coherent organizational identity facilitates organizational governance by providing an organizational narrative for creating social value (Tate and Bals 2018). Research in social enterprises suggests that failure to develop an (hybrid) identity inhibits collective action as employees fail to converge on a course of action or different goals guide action at different times (Ramus and Vacarro 2017). The presence of a mission-driven identity reinforces organizational commitment, which is crucial for circumventing structural constraints (Halme et al. 2012) and coping with ethical dilemmas that inhibit social value creation. Since building BoP businesses will require a time-taking and iterative process of experimentation and learning (Yunus et al. 2010; Duke 2016), the space, time, and resources needed to grow to scale are unlikely to be available in organizations that lack mission-drive at the top level.

Because of the normative nature of their goals, BoP businesses grapple with fundamental ethical questions such as what constitutes social value, and for whom and how it should be created (Osorio-Vega 2019). These ethical issues tend to be morally compelling as they involve vulnerable communities who are prone to exploitation due to informational, economic, and cultural disadvantages (Arnold and Valentin 2013). Many BoP businesses have been criticized for introducing changes in the lives of individuals, families, communities, and societies that give rise to detrimental social outcomes (Karnani 2007). Doing business with BoP communities is thus a morally charged terrain that requires a process of reflexive inquiry to question the validity of taken-for-granted ideas, concepts, and assumptions (Chatterjee 2014). This requires an organizational culture of deep reflection and care to anticipate and avert potential undesired socio-economic effects of organizational interventions. A careful management of ethical dilemmas is hence an important contingency in successful social value creation that could create a legitimacy crisis if it is not successfully managed.

\section{External Contingencies}

Structural conditions related to industry structure, national economies, and institutions influence the performance of BoP businesses. For example, businesses in consumer markets such as Unilever and Philips were among the first to adapt their products to the needs of BoP consumers. This is potentially because of their proximity with low-income

\footnotetext{
$\overline{2}$ We identify organizational identity as a contingent factor based on the view that identities, while sometimes amenable to change, evolve very slowly and are generally beyond the control of individual managers (Dentoni et al. 2018).
}

consumers, which resulted in greater information and better understanding of their needs. This is also apparent from the adoption patterns of fair trade and other sustainable practices, which are common in consumer markets such as coffee retailers, and clothing and fashion industries. In contrast, business-to-business firms that do not confront social issues on a daily basis might be less motivated to make similar adaptations.

The nature and size of the industries can affect the extent to which BoP ventures can achieve scale. Telecom firms in countries like Kenya, Bangladesh, South Africa, and the Philippines have been relatively successful in launching social innovations such as mobile banking. In Bangladesh, Grameen Phone has managed to expand its market reach while also reducing poverty through an initiative that empowers the rural poor with access to information and resources to enable them to start their own businesses (Rahman et al. 2014). In Kenya, Safaricom has succeeded in developing a range of social innovations that advance empowerment in sectors as diverse as health, agriculture, education, and transportation (Lashitew et al. 2018). This level of success could be difficult to replicate in other industries where social and commercial goals are difficult to reconcile due to technological and market-related reasons.

The size and structure of the market is another important factor in social value creation efforts. The presence of alternative financing sources that can fund impact investment, from development organizations or private investors, can determine the effectiveness of value chain integration efforts by BoP businesses (London and Anupindi 2012). In contexts where the state is better-run and public service provision is strong, the business incentives for providing such services will be relatively low. Likewise, the regulatory environment can play a fundamental role, especially for firms that operate in heavily regulated sectors such as finance and telecom. The willingness of the regulator to facilitate processes of institutional change and adaptation can be a crucial precondition for the success of new business models (Prado et al. 2016). Many social enterprises and grassroots ventures also suffer from poor cognitive legitimacy that deters local governments from providing regulatory support and economic incentives (Goyal et al. 2015).

\section{Social Value Creation Outcomes}

\section{Aspects of Social Value}

Social value creation entails bringing about improvements in the socio-economic well-being of BoP communities. Our review identified three specific aspects of social value creation: addressing the needs of BoP communities, developing their capabilities, and mitigating the externalities of BoP businesses. First, there is strong emphasis on the 
satisfaction of fundamental needs as a major criterion for assessing social value creation. Dembek et al. (2016) suggest the need to consider three crucial aspects of social value, namely: (1) What needs are addressed; (2) How they are addressed; and (3) If they are satisfied. Building on Prahalad (2004), Anderson and Billou (2007) suggest the $4 \mathrm{~A}$ criteria for evaluating success in meeting fundamental social needs: affordability, availability, acceptability, and awareness. These criteria indicate that an important element of social value creation is fine-tuning the value offerings of $\mathrm{BoP}$ businesses towards addressing the pressing bottlenecks of BoP communities. Although the primary focus is on economic needs, social value creation could target health and educational needs, social development (e.g., empowerment and self-esteem) and social justice (e.g., fair access to public services) (Mair et al. 2012). Businesses adopt a wider conception of social value that includes economic, social, and normative needs, in part because they often go hand-in-hand. For example, women microentrepreneurs who gained access to microfinance saw improvements in their profitability, which in return developed their subjective well-being and self-esteem, although this relationship is contingent and not always guaranteed (Bhuiyan and Ivlevs 2019).

Second, there is currently a shift of emphasis towards cocreating value with beneficiaries, and particularly developing their capabilities (Ansari et al. 2012). Selling goods to the poor can be seen as a "surface-level" strategy while achieving systemic change entails improving current capabilities, rules, or practices (Stephan et al. 2016). Organizations, therefore, are advised to focus on purposefully and strategically shaping the institutional environment to create lasting and significant (widespread) social value (London and Hart 2011). A well-known example of a business model that introduced such as systemic change is microfinance, while another more recent example is mobile money innovation, which allows users to use their mobile phones to open virtual bank accounts that support money transfer and other functions (Lashitew et al. 2018). These innovations are unique for advancing positive social change through new business models that included previously disenfranchised social groups as players in the business ecosystem (Stephan et al. 2016).

Finally, there is increasing emphasis on assessing and mitigating the unintended indirect effects, or externalities, which are often neglected by practitioners due to the difficulty to assess them definitively. Externalities can be positive or negative, and refer to indirect, long-term outcomes that are attributable to interventions by BoP businesses. Negative externalities in the form of increased inequality, crime, and decline of subjective well-being can reduce overall social value (Bhuiyan and Ivlevs 2019; Hall et al. 2012), whereas positive externalities in the form of institutional change can lead to a lasting improvement in social value (Rivera-Santos et al. 2012).

\section{Assessing Net Social Value}

Assessing net social value involves identifying and evaluating the causal "impact pathway" that links specific business strategies with changes in the well-being of targeted BoP societal segments (London et al. 2010; Seelos and Mair 2005). Targeted beneficiaries can be employees, distributors, suppliers, the government or community members or actors outside the value chain (Mair et al. 2012). This type of assessment is, however, complicated by the absence of clear standards of measurement, the multidimensionality of social value, and the subjective, often normative, nature of certain outcomes. As a result, most approaches for social impact measurement focus on intermediate results such as output (e.g., number of microfinance clients) and outcomes (amount of credit disbursement), rather than the eventual impact (change in income and other economic outcomes). These approaches will only offer a partial assessment, since getting the full picture will require assessing both processes and outcomes of social value creation (London 2009; Dembek et al. 2016; Bals and Tate 2018).

The multidimensionality of social value also makes it difficult to assess performance using a single, objective indicator that applies across economic sectors. Even for economic outcomes, aggregation across actors becomes difficult because interventions often have uneven effects across stakeholders, sometimes increasing inequalities even when they raise average income at community level (Stephan et al. 2016; Hall et al. 2012). Quantification is particularly daunting for subjective outcomes, although there is some progress in providing a clearer conceptualization for such outcomes. For example, London (2009) emphasizes the need to assess positive and negative changes in both financial and non-financial aspects of well-being, and proposes assessing changes in the economic situation, capabilities, and relationships of the firm's key constituencies. London and Esper (2014) apply the same framework to map out the impact of a BoP business in Nairobi, while London et al. (2014) quantitatively show that, contingent upon the strength of formal institutions, these multiple dimensions of well-being influence customers' decisions to purchase products offered by BoP businesses. Scott et al. (2012) likewise find that BoP businesses empower women along multiple dimensions of well-being (including finance, self-esteem, networking, and capabilities). While these and similar other studies (e.g., Dolan and Scott 2009) emphasize the multidimensionality of social value, few BoP businesses successfully measure and track their own progress, which limits their ability to systematically build on their experiences to create social value (Stephan et al. 2016). 
The lack of broadly accepted measurement standards introduces a challenge for BoP businesses in communicating their goals and strategies (Dembek et al. 2019). The resulting equivocal understanding of social value creates a legitimacy challenge for BoP businesses, which could struggle to gain acceptance among key external audiences. This has exacerbated the risk of mission drift in social businesses (Ramus and Vaccaro 2017), leading to a goal asymmetry in favor of quantifiable, often economic, metrics of performance (Halme et al. 2012). Greater reliance on economic concepts in justifying social value creation can in turn undermine social value creation by rendering social issues as "instrumental" to financial goals (Hart 2005). These complexities in assessing social value call for specialized assessment methods to increase the affordability and feasibility of performance evaluation.

\section{Unfavorable Ethical Outcomes}

Strong emphasis on economic outcomes to the exclusion of normative ones (such as self-reliance, social justice, and social cohesion) can affect the ethical grounding and performance of social value creation processes and outcomes (Osorio-Vega 2019). A poor handling of the multitude of ethical dilemmas in BoP businesses could lead to at least four types of unfavorable ethical outcomes.

\section{A. Commercializing poverty/undermining local welfare:}

BoP businesses that discover a clear market need will still be challenged by the contentious question of how much is a "fair price" to charge the poor. BoP businesses that provide life-sustaining or essential goods and services such as water, food, and healthcare thus face the ethical dilemma of being seen as gaining pecuniary advantages out of the suffering of the poor (Karnani 2007). Business-led approaches for poverty alleviation are thus susceptible for loss of legitimacy, especially when they inadvertently introduce undesired cultural changes such as consumerism, alcoholism, or tobacco addiction.

B. Unfair terms of inclusion and exclusion: Although BoP businesses aspire to advance inclusion, they are often forced to set up certain terms of exclusion to ensure financial sustainability. For instance, businesses that seek to empower subsistence farmers tend to include more productive firms in their supply chain, and those aiming to create employment opportunities hire the relatively skilled rather than the very poor. This creates an imperative for greater transparency about the terms of inclusion in social value creation initiatives, so that noncommercial entities can cater to the needs of the very poor who are left out.
C. Unintended social disruption: Many interventions could have unintended unethical outcomes on BoP communities such as disruptions in power structures, social stability, and changes in cultural attitudes. For example, interventions that aim to empower women could end up destabilizing families and increasing divorce rates (London 2009). Likewise, initiatives that have unequal impact across communities could create tensions among ethnic, religious, and cultural groups. The low literacy level of the poor could expose them to irrational choices, making it necessary for businesses to exercise high levels of ethical sensitivity (Gollakota et al. 2010; Karnani 2007).

D. Increasing dependency on (international) businesses: BoP businesses could end up making communities dependent on the services of profit-making businesses if they inadvertently crowd out government investment on public service provision (Dembek et al. 2016). BoP communities could thus be locked into a system where public services such as education, healthcare, and water are provided by businesses that are not directly accountable to them. This outcome is contradictory to the aspiration of creating social value that improves the self-esteem of the poor and frees them from servitude (Sinkovics et al. 2014). When commercial approaches are practically feasible but not ethically justifiable, managers would have to pursue alternative approaches such as supporting communities and local governments to build their own capabilities.

\section{An Overview of the Social Value Creation Framework}

Our social value creation framework (Fig. 5) characterizes the process of social value creation in terms of motivational antecedents, capabilities, and outcomes, which are shaped by various constraints and contingencies. The framework provides a rich account of the various elements of BoP businesses that underpin social value creation processes and outcomes.

Most of the literature adopts a cross-sectional case study method (see Appendix Fig. A5), often focusing on a single construct at a time. There is hence limited evidence on how the various components of BoP business models interact with each other in shaping the social value creation outcomes. There is some evidence that purpose-driven motives enable long-term and costly investments for developing organizational capabilities that are required to support sustained and transformative social value creation (Lashitew et al. 2018). Moreover, purpose-driven businesses are likely to develop a deeper understanding of the fundamental issues behind social problems due to their closer engagement with local communities (Hart et al. 2016). There is unfortunately scant comparative research that assesses the relative effects 
of economic- and purpose-driven motives on capability development and social value creation.

Different capabilities are likely to become important for advancing social value depending on the internal and external organizational environment. For instance, ecosystem building will be more meaningful in locations that suffer from significant institutional voids and resource scarcity (Sánchez and Ricart 2010), and in economic sectors that involve complex and extended supply chains (Caneque and Hart 2017). Likewise, the questions of with whom and how to collaborate will depend on the asset requirements of the initiative (London and Jäger 2019). Social capital can provide a more effective governance mechanism in contexts with strong social cohesion, while new technologies such as ICT become important where physical infrastructure is poorly developed (London and Hart 2011). However, more research is needed to provide granular evidence on the complex relationships between external constraints/ contingencies and internal capabilities, and their effects on performance.

We have already noted that social value creation is an iterative process involving multiple learning loops. Our framework in Fig. 5 captures this through arrows that run from final outcomes to antecedents and capabilities, highlighting that organizational change towards social value creation is a gradual, step-wise process (Pache and Santos 2013). Like all businesses, BoP businesses also learn from their experiences and respond by retooling their strategies and capabilities. Small-scale initiatives can lead to more intensive, sustained engagement with social issues if they enable organizational change by allowing the fusion of values, practices, and norms (Battilana and Lee 2014). Experimental initiatives that lead to significant financial gains and recognition for social impact can initiate a transformative change towards a mission-driven identity (Lashitew et al. 2018). Once introduced, such identities can counteract the risk of mission drift that supplants social goals with financial ones (Ramus and Vaccaro 2017). When primordial motives crystalize into mission-driven identities, initial "commitment" for social issues transforms into "consistent" efforts that sustain social engagement (Tate and Bals 2018).

Small-scale experimentation can thus elicit "learning-bydoing", and even provide a turning point for forming new identities through learning "who we are" as an organization (Dentoni et al. 2018). However, the impact loop could also be negative if initiatives fail to create social value or introduce significant ethical dilemmas. For example, BoP businesses that face media backlash for "commercializing poverty" are likely to respond by backtracking from their effort to create social value. In cases where motives are highly economic-driven, successful social value creation is also likely to reinforce future initiatives if it also improves financial performance.

\section{Discussion and Conclusion}

This section builds on our integrative review of the managerial and organizational processes for social value creation to outline promising directions for future research.

\section{Research Agenda}

Research into BoP businesses has come a long way from exploring fundamental questions on the feasibility or appropriateness of social value creation that preoccupied the early literature. Our review has shown that research has started to address complex questions on conceptualizing and measuring social impact, and laying out the internal capabilities and external contingencies that influence social value creation. In spite of significant progress, there remain notable knowledge gaps in a number of areas as discussed below.

\section{Theoretical Approaches}

Our analysis revealed that the literature draws on a very limited range of theoretical approaches related to internationalization theory, business strategy, innovation studies, and marketing (Fig. 2). Most research on the topic focusses on external constraints faced by firms, while scant attention is given to the organizational processes for creating social value (Olsen and Boxenbaum 2009). Very few studies take a theoretically grounded approach towards understanding the mechanisms through which organizations create social value for the BoP.

The complexity of the topic of social value creation and its broad scope offer an opportunity to draw on a broader spectrum of theoretical traditions and perspectives. There is an encouraging trend in using institutional theory for understanding how actors shape the broader business ecosystem through processes of institutional entrepreneurship (George et al. 2015; Mair and Marti 2009). Researchers can also seek to integrate the Resource-Based View (RBV) with internationalization theory to unpack the conditions under which MNEs are able to transfer, deploy, and exploit their firm-specific advantages (Hillemann and Verbeke 2014). Agency theory can be highly useful for understanding the complex governance challenges of purpose-driven BoP businesses. Since creating social value in a commercial enterprise entails complex governance and legitimacy challenges (Ramus and Vacarro 2017; Kistruck et al. 2016), researchers could explicate how innovations in governance and goal structures can help overcome these limitations. Identity theory can be likewise highly relevant for understanding how BoP businesses develop mission-driven organizational identities to blunt organizational challenges and legitimize 
hybrid organizational goals (Battilana and Lee 2014; Pache and Santos 2013). Theories of cognitive psychology can be useful for characterizing the managerial frames and mental templates of ambidextrous social entrepreneurs and managers. These theories can inform the types of managerial practices that are needed to successfully steer BoP businesses that face complex goal functions (Van der Byl and Slawinski 2015). The field is particularly ripe for cross-disciplinary work that draws on multiple perspectives to provide a more elaborate understanding of the organizational mechanisms for creating social value.

\section{The Empirics of Research}

Our analysis has revealed that the literature for the most part relies on exploratory case studies and deductive, conceptual work. Rigorous research that aims to develop coherent theoretical arguments and test them empirically is considerably lacking. While this reflects the emerging nature of the field, the field's development and reputation will hinge on the emergence of a research body that rigorously tests and elaborates theoretical relationships. Coupled with the effort to guide research with sound theory, there is a need for sound empirical research that makes use of in-depth qualitative analysis and large-scale quantitative approaches.

Our review shows that much of the empirical literature is informed by successful cases (Fig. A6), which limits its ability to generate fine-grained understanding of determinants of success. We also find very limited focus on organizational processes for creating social value, since much of the literature focuses on external issues related to the institutional, market, and technological environment (Halme et al. 2012). There is hence an important gap in identifying how internal structures, capabilities, and processes interact with external contingencies in influencing the ability of BoP businesses to create social value. For example, future research can illuminate how firms can adopt cocreation to broaden the scope of their asset base in terms of economic, knowledge, leadership, network, and innovation assets (London and Jäger 2019).

While our review revealed a broad range of capabilities that have been identified as important for BoP businesses, the literature is less specific as to which capabilities are needed under what contingencies. Each arrow of the social value creation framework (Fig. 5) can thus be subjected to solid empirical research. This can improve our understanding of how different organizational motives shape capability development, and the conditions under which different capabilities can help mitigate specific constraints that limit social value creation. More broadly, researchers can look into specific boundary conditions, such as governance structures or institutional conditions that influence social value creation.

\section{Institutional and Governance Change}

Research suggests that the most systemic form of change involves altering institutional structures, which include both informal meaning systems and formal governance systems (Stephan et al. 2016). Current research is silent on how organizations can change governance institutions, although Prahalad's seminal work had emphasized the need to work with governments to improve their accountability, efficiency, and transparency. Subsequent research has shied away from the challenge of transforming institutions, instead emphasizing the use of informal networks and social capital as substitutes for inefficient formal structures (e.g., Hart and London 2005). This has led to critiques that the literature inadvertently advances the neoliberalist ideology of state withdrawal from welfare policies (Ansari et al. 2012).

The limited role attributed to governments is in part due to the (perceived) ineffectiveness and poor legitimacy of government institutions in lower-income countries. Moreover, working with governmental actors could introduce new types of risk that complicate relationships with the government and other local actors (Reficco and Márquez 2012). For partnerships that seek to alter institutional structures, however, working closely with government bodies can be an effective way of facilitating the formalization of small-scale institutional changes. Partnering with (local) governments can also offer the advantage of leveling out the playing field and reducing power asymmetries. In the absence of strong media or civic organizations, the significant financial and political power of MNEs can give them a carte blanche to steer change in their own terms, potentially at the expense of local communities (Sinkovics et al. 2014). Working with government bodies could thus attenuate power asymmetries in partnerships and enhance local legitimacy and accountability. Future research can illuminate the opportunities and risks associated with the purposeful pursuit of institutional change from the perspectives of $\mathrm{BoP}$ businesses and communities.

\section{Analyzing Aggregate Social Value}

Greater effort is needed to conceptualize, measure, and analyze social value to better understand the conditions under which BoP businesses are able to improve the well-being of local communities. Evaluating the impact of BoP businesses will require taking a broader perspective by adopting macro (e.g., national) or meso (regional or local) levels of analysis since firm-level analysis is unlikely to capture the multifaceted nature of social value. A more extensive approach is needed in assessing social impact that goes beyond economic metrics and includes capabilities and social wellbeing such as freedom and empowerment (Ansari et al. 2012). For example, Jackson and Young (2016) find that 
the explosion of microfinance markets in Bangladesh led to a breakdown of traditional social networks, and increased pressure and shame among indebted families, who suffered from heavy-handed lenders. Likewise, Hall et al. (2012) document how the growth of the tourism industry in Brazil was followed by exacerbated inequalities and social exclusion. These kinds of changes in aggregate social structures and relationships can only be captured by taking villages, communities, and regions as levels of analysis.

\section{Concluding Remark}

This systematic review has sought to address an important research gap on the complex process of social value creation among BoP businesses. We have developed a framework that sheds light on the dynamic interplay between internal business model elements and external conditions that influence social value creation for the BoP. The framework laid out two major categories of antecedents, three groups of constraints, five types of capabilities, and two types of contingencies that influence social value creation. Our review also explored the nature of social value, the challenges of measuring it, and the associated ethical dilemmas. Based on our critical review of the literature, we have identified four broad research areas that can address important knowledge gaps in the field.

We would like to conclude by mentioning some limitations. First, the specific elements of our framework are likely to differ across contexts, industries, and even specific firms. The framework is not meant to capture the full extent of social value creation mechanisms, but instead provide a skeleton that forms a basis for more granular research in more specific domains or contexts. Since neither the analysis nor the resulting framework is by any means exhaustive, future research can help identify additional business model elements and contingencies that improve our understanding of social value creation processes. We nonetheless hope that our analysis will help streamline the discourse and facilitate interaction among the various research streams that look into social value creation.

Funding Open Access funding enabled and organized by Projekt DEAL. There is no specific funding to declare for this study.

\section{Compliance with Ethical Standards}

Ethical Approval All procedures performed in studies involving human participants were in accordance with the ethical standards of the institutional and/or national research committee and with the 1964 Helsinki declaration and its later amendments or comparable ethical standards.
Informed Consent Informed consent was obtained from all individual participants included in the study.

Open Access This article is licensed under a Creative Commons Attribution 4.0 International License, which permits use, sharing, adaptation, distribution and reproduction in any medium or format, as long as you give appropriate credit to the original author(s) and the source, provide a link to the Creative Commons licence, and indicate if changes were made. The images or other third party material in this article are included in the article's Creative Commons licence, unless indicated otherwise in a credit line to the material. If material is not included in the article's Creative Commons licence and your intended use is not permitted by statutory regulation or exceeds the permitted use, you will need to obtain permission directly from the copyright holder. To view a copy of this licence, visit http://creativecommons.org/licenses/by/4.0/.

\section{References}

Aiyar, A., \& Venugopal, S. (2019). Addressing the ethical challenge of market inclusion in base-of-the-pyramid markets: A macromarketing approach. Journal of Business Ethics. https://doi. org/10.1007/s10551-019-04275-9.

Anderson, J., \& Billou, N. (2007). Serving the world's poor: Innovation at the base of the economic pyramid. Journal of Business Strategy, 28(2), 14-21.

Angeli, F., \& Jaiswal, A. K. (2016). Business model innovation for inclusive health care delivery at the Bottom of the Pyramid. Organization \& Environment, 29(4), 486-507.

Ansari, S., Munir, K., \& Gregg, T. (2012). Impact at the 'bottom of the pyramid': The role of social capital in capability development and community empowerment. Journal of Management Studies, 49(4), 813-842.

Arnold, D. G., \& Valentin, A. (2013). Corporate social responsibility at the base of the pyramid. Journal of Business Research, 66(10), 1904-1914.

Arora, B., \& Kazmi, S. B. A. (2012). Performing citizenship: An innovative model of financial services for rural poor in India. Business and Society, 51(3), 450.

Ausrød, V. L., Sinha, V., \& Widding, Ø. (2017). Business model design at the base of the pyramid. Journal of Cleaner Production, 162, 982-996.

Bals, L., \& Tate, W. L. (2018). Sustainable supply chain design in social businesses: advancing the theory of supply chain. Journal of Business Logistics, 39(1), 57-79.

Barrie, J., \& Cruickshank, H. J. (2017). Shedding light on the last mile: A study on the diffusion of Pay-as-You-Go Solar Home Systems in Central East Africa. Energy Policy, 107, 425-436.

Battilana, J., \& Lee, M. (2014). Advancing research on hybrid organizing-Insights from the study of social enterprises. The Academy of Management Annals, 8(1), 397-441.

Bendul, J. C., Rosca, E., \& Pivovarova, D. (2017). Sustainable supply chain models for base of the pyramid. Journal of Cleaner Production, 162, 107-120.

Beninger, S., \& Robso, K. (2015). Marketing at the base of the pyramid: Perspectives for practitioners and academics. Business Horizons, 58(5), 509.

Bhuiyan, M. F., \& Ivlevs, A. (2019). Micro-entrepreneurship and subjective well-being: Evidence from rural Bangladesh. Journal of Business Venturing, 34(4), 625-645.

Bocken, N. M. P., Fil, A., \& Prabhu, J. (2016). Scaling up social businesses in developing markets. Journal of Cleaner Production, 139, 295-308. 
Brugmann, J., \& Prahalad, C. K. (2007). Cocreating business's new social compact. Harvard Business Review, 85(2), 80-90.

Braun, V., \& Clarke, V. (2006). Using thematic analysis in psychology. Qualitative Research in Psychology, 3(2), 77-101.

Calton, J. M., Werhane, P. H., Hartman, L. P., \& Bevan, D. (2013). Building partnerships to create social and economic value at the base of the global development pyramid. Journal of Business Ethics, 117(4), 721-733.

Caneque, F. C., \& Hart, S. L. (Eds.). (2017). Base of the Pyramid 3.0: Sustainable Development through Innovation and Entrepreneurship. Sheffield: Greenleaf Publishing Limited.

Chatterjee, S. (2014). Engaging with an emergent metanarrative: A critical exploration of the BoP proposition. Organization, 21(6), 888.

Chesbrough, H., Ahern, S., Finn, M., \& Guerraz, S. (2006). Business models for technology in the developing world: The role of non-governmental organizations. California Management Review, 48(3), 48-61.

Chliova, M., \& Ringov, D. (2017). Scaling impact: Template development and replication at the base of the pyramid. Academy of Management Perspectives, 31(1), 44-62.

Christensen, C. M., \& Baumann, H. (2006). Disruptive innovation for social change. Harvard Business Review, 84(12), 94.

Christensen, L. J., Parsons, H., \& Fairbourne, J. (2010). Building entrepreneurship in subsistence markets: Microfranchising as an employment incubator. Journal of Business Research, 63(6), 595.

Davidson, D. K. (2009). Ethical concerns at the bottom of the pyramid: where CSR meets BoP. Journal of International Business Ethics, 2(1), 22-32

Dembek, K., Singh, P., \& Bhakoo, V. (2016). Literature review of shared value: A theoretical concept or a management buzzword? Journal of Business Ethics, 137(2), 231-267.

Dembek, K., Sivasubramaniam, N., \& Chmielewski, D. A. (2019). A systematic review of the bottom/base of the pyramid literature: Cumulative evidence and future directions. Journal of Business Ethics. https://doi.org/10.1007/s10551-019-04105-y.

Dentoni, D., Bitzer, V., \& Pascucci, S. (2016). Cross-sector partnerships and the cocreation of dynamic capabilities for stakeholder orientation. Journal of Business Ethics, 135(1), 35-53.

Dentoni, D., Pascucci, S., Poldner, K., \& Gartner, W. B. (2018). Learning "who we are" by doing: Processes of co-constructing prosocial identities in community-based enterprises. Journal of Business Venturing, 33(5), 603-622.

Di Stefano, G., Peteraf, M., \& Verona, G. (2010). Dynamic capabilities deconstructed: A bibliographic investigation into the origins, development, and future directions of the research domain. Industrial and Corporate Change, 19(4), 1187-1204.

Dolan, C., \& Scott, L. (2009). Lipstick evangelism: Avon trading circles and gender empowerment in South Africa. Gender \& Development, 17(2), 203-218.

Duke, D. (2016). Why don't BoP ventures solve the environmental problems they initially set out to address? Organization \& Environment, 29(4), 508-528.

Eisenhardt, K. M., \& Graebner, M. E. (2007). Theory building from cases: Opportunities and challenges. Academy of Management Journal, 50(1), 25-32.

Garrette, B., \& Karnani, A. (2010). Challenges in marketing socially useful goods to the poor. California Management Review, 52(4), 29-47.

Gebauer, H., Saul, C. J., \& Haldimann, M. (2017). Business model innovation in base of the pyramid markets. Journal of Business Strategy, 38(4), 38-46.

George, G., McGahan, A. M., \& Prabhu, J. (2012). Innovation for inclusive growth: Towards a theoretical framework and a research agenda. Journal of Management Studies, 49(4), 661-683.
George, G., Rao-Nicholson, R., Corbishley, C., \& Bansal, R. (2015). Institutional entrepreneurship, governance, and poverty: Insights from emergency medical response services in India. Asia Pacific Journal of Management, 32(1), 39-65.

Gollakota, K., Gupta, V., \& Bork, J. T. (2010). Reaching customers at the base of the pyramid: A two-stage business strategy. Thunderbird International Business Review, 52(5), 355.

Goyal, S., Sergi, B. S., \& Jaiswal, M. (2015). How to design and implement social business models for base-of-the-pyramid (BoP) markets? European Journal of Development Research, 27(5), 850-867.

Gradl, C., Krämer, A., \& Amadigi, F. (2010). Partner selection for inclusive business models. Greener Management International, $56,25-42$.

Haffar, M., \& Searcy, C. (2017). Classification of trade-offs encountered in the practice of corporate sustainability. Journal of Business Ethics, 140(3), 495-522.

Hahn, R. (2009). The ethical rational of business for the poor-integrating the concepts bottom of the pyramid, sustainable development, and corporate citizenship. Journal of Business Ethics, 84(3), 313-324.

Hahn, T., Pinkse, J., Preuss, L., \& Figge, F. (2016). Ambidexterity for corporate social performance. Organization Studies, 37(2), 213-235.

Hall, J., Matos, S., Sheehan, L., \& Silvestre, B. (2012). Entrepreneurship and innovation at the base of the pyramid: A recipe for inclusive growth or social exclusion? Journal of Management Studies, 49(4), 785-812.

Halme, M., Lindeman, S., \& Linna, P. (2012). Innovation for inclusive business: Intrapreneurial bricolage in multinational corporations. Journal of Management Studies, 49(4), 743-784.

Hammond, A. L., Kramer, W. J., Katz, R. S., Tran, J. T., \& Walker, C. (2007). The next four billion: Market size and business strategy at the base of the Ppyramid. Washington, DC: World Resources Institute, International Finance Corporation.

Hart, S. L., \& London, T. (2005). Developing native capability. Stanford Social Innovation Review, 3(2), 28-33.

Hart, S. L. (2005). Capitalism at the crossroads: The unlimited business opportunities in solving the world's most difficult problems. London: Pearson Education.

Hart, S., Sharma, S., \& Halme, M. (2016). Poverty, business strategy, and sustainable development. Organization \& Environment, 29(4), 401-415.

Hillemann, J., \& Verbeke, A. (2014). An internalization theory perspective on the Bottom of the Pyramid. International Business and Sustainable Development (pp. 69-90). Bingley: Emerald Group Publishing Limited.

Ireland, J. (2008). Lessons for successful BoP marketing from Caracas' slums. Journal of Consumer Marketing, 25(7), 430-438.

Jack, S. L., \& Anderson, A. R. (2002). The effects of embeddedness on the entrepreneurial process. Journal of Business Venturing, 17(5), 467-487.

Jackson, L., \& Young, L. (2016). When business networks "kill” social networks: A case study in Bangladesh. Industrial Marketing Management, 58, 148-161.

Karnani, A. (2007). The mirage of marketing to the bottom of the pyramid: How the private sector can help alleviate poverty. California Management Review, 49(4), 90-111.

Kelly, W. L., Rosa, J. A., \& Viswanathan, M. (2010). Marketing to subsistence consumers: Lessons from practice. Journal of Business Research, 63(6), 559-569.

Khalid, R. U., \& Seuring, S. (2017). Analyzing base-of-the-pyramid research from a (sustainable) supply chain perspective. Journal of Business Ethics, 155, 663-686. 
Kistruck, G. M., \& Beamish, P. W. (2010). The interplay of form, structure, and embeddedness in social intrapreneurship. Entrepreneurship Theory and Practice, 34(4), 735-761.

Kistruck, G. M., Sutter, C. J., Lount, J. R., et al. (2013). Mitigating principal-agent problems in base-of-the-pyramid markets: An identity spillover perspective. Academy of Management Journal, 56(3), 659-682.

Kistruck, G. M., Lount, R. B., Jr., Smith, B. R., Bergman, B. J., \& Moss, T. W. (2016). Cooperation vs. competition: Alternative goal structures for motivating groups in a resource scarce environment. Academy of Management Journal, 59(4), 1174-1198.

Kolk, A., Rivera-Santos, M., \& Rufín, C. (2014). Reviewing a decade of research on the "Base/Bottom of the pyramid" (BoP) concept. Business \& Society, 53(3), 338-377.

Kolk, A., \& van den Buuse, D. (2012). In search of viable business models for development: Sustainable energy in developing countries. Corporate Governance: The International Journal of Business in Society, 12(4), 551-567.

Lashitew, A. A., Bals, L., \& van Tulder, R. (2018). Inclusive business at the base of the pyramid: The role of embeddedness for enabling social innovations. Journal of Business Ethics, 162, 421.

Le Ber, M. J., \& Branzei, O. (2010). (Re)forming strategic crosssector partnerships: Relational processes of social innovation. Business \& Society, 49(1), 140-172.

Leydesdorff, L. (2008). On the normalization and visualization of author co-citation data: Salton's Cosine versus the Jaccard index. Journal of the American Society for Information Science and Technology, 59(1), 77-85.

Lim, C., Han, S., \& Ito, H. (2013). Capability building through innovation for unserved lower end mega markets. Technovation, 33(12), 391-404.

London, T. (2009). Making better investments at the base of the pyramid. Harvard Business Review, 87(5), 106-113.

London, T. (2008). The base-of-the-pyramid perspective: A new approach to poverty alleviation. Academy of Management Proceedings, 2008(1), 1-6.

London, T., Anupindi, R., \& Sheth, S. (2010). Creating mutual value: Lessons learned from ventures serving base of the pyramid producers. Journal of Business Research, 63(6), 582-594.

London, T., \& Anupindi, R. (2012). Using the base-of-the-pyramid perspective to catalyze interdependence-based collaborations. Proceedings of the National Academy of Sciences, 109(31), 12338-12343.

London, T., \& Esper, H. (2014). Assessing poverty-alleviation outcomes of an enterprise-led approach to sanitation. Annals of the New York Academy of Sciences, 1331, 90-105.

London, T., Esper, H., Grogan-Kaylor, A., \& Kistruck, G. (2014). Connecting poverty to purchase in informal markets. Strategic Entrepreneurship Journal, 8(1), 37-55.

London, T., \& Hart, S. L. (2004). Reinventing strategies for emerging markets: Beyond the transnational model. Journal of International Business Studies, 35, 350-370.

London, T., \& Hart, S. L. (Eds.). (2011). Next generation business strategies for the base of the pyramid: New approaches for building mutual value. London: Pearson Education India.

London, T., \& Jäger, U. (2019). Cocreating with the base of the pyramid. Stanford Social Innovation Review, 16(3), 40-47.

Mair, J., \& Marti, I. (2006). Social entrepreneurship research: A source of explanation, prediction, and delight. Journal of World Business, 41(1), 36-44.

Mair, J., \& Marti, I. (2009). Entrepreneurship in and around institutional voids: A case study from Bangladesh. Journal of Business Venturing, 24(5), 419-435.

Mair, J., Martí, I., \& Ventresca, M. J. (2012). Building inclusive markets in rural Bangladesh: How intermediaries work institutional voids. Academy of Management Journal, 55(4), $819-850$

Mair, J., \& Noboa, E. (2006). Social entrepreneurship: How intentions to create a social venture are formed. Social Entrepreneurship (pp. 121-135). London: Palgrave Macmillan.

Matos, S., \& Silvestre, B. S. (2013). Managing stakeholder relations when developing sustainable business models: The case of the Brazilian energy sector. Journal of Cleaner Production, 45, 61-73.

Nahapiet, J., \& Ghoshal, S. (1998). Social capital, intellectual capital, and the organizational advantage. Academy of Management Review, 23(2), 242-266.

Nahi, T. (2016). Cocreation at the base of the pyramid: Reviewing and organizing the diverse conceptualizations. Organization \& Environment, 29(4), 416-437.

Nielsen, C., \& Samia, P. M. (2008). Understanding key factors in social enterprise development of the BoP: A systems approach applied to case studies in the Philippines. Journal of Consumer Marketing, 25(7), 446-454.

North, D. (1990). Institutions and their consequences for economic performance. The limits of rationality (pp. 383-401). Chicago: University of Chicago Press.

Olsen, M., \& Boxenbaum, E. (2009). Bottom-of-the-pyramid: Organizational barriers to implementation. California Management Review, 51(4), 100-125.

Osorio-Vega, P. (2019). The ethics of entrepreneurial shared value. Journal of Business Ethics, 157(4), 981-995.

Pache, A. C., \& Santos, F. (2013). Inside the hybrid organization: Selective coupling as a response to competing institutional logics. Academy of Management Journal, 56(4), 972-1001.

Panapanaan, V., Bruce, T., Virkki-Hatakka, T., \& Linnanen, L. (2016). Analysis of shared and sustainable value creation of companies providing energy solutions at the base of the pyramid (BoP). Business Strategy and the Environment, 25(5), 293-309.

Parmigiani, A., \& Rivera-Santos, M. (2015). Sourcing for the base of the pyramid: Constructing supply chains to address voids in subsistence markets. Journal of Operations Management, 33, 60-70.

Perez-Aleman, P., \& Sandilands, M. (2008). Building value at the top and the bottom of the global supply chain: MNC-NGO partnerships. California Management Review, 51(1), 24-49.

Pfitzer, M., Bockstette, V., \& Stamp, M. (2013). Innovating for shared value. Harvard Business Review, 91(9), 100-107.

Pitta, D. A., Guesalaga, R., \& Marshall, P. (2008). The quest for the fortune at the bottom of the pyramid: Potential and challenges. Journal of Consumer Marketing, 25(7), 393-401.

Porter, M. E., \& Kramer, M. R. (2011). Creating shared value: Redefining capitalism and the role of the corporation in society. Harvard Business Review, 89(1/2), 62-77.

Prado, A. M., Calderon, D., \& Zúñiga, R. (2016). Providing low-cost and high-quality medications to rural communities in developing countries: The case of Accion Medica Cristiana in Nicaragua. Journal of Business Research, 69(9), 3910-3922.

Prahalad, C. K. (2004). The fortune at the bottom of the pyramid: Eradicating poverty through profits. Upper Saddle River, NJ: Wharton School Publishing.

Prahalad, C. K. (2012). Bottom of the pyramid as a source of breakthrough innovations. Journal of Product Innovation Management, 29(1), 6-12.

Prahalad, C. K., \& Hammond, A. (2002). Serving the world's poor, profitably. Harvard Business Review, 80(9), 48-59.

Prahalad, C. K., \& Hart, S. (2002). The fortune at the bottom of the pyramid. Strategy Business, 26, 54-67.

Rahman, S. A., Amran, A., Ahmad, N. H., \& Taghizadeh, S. K. (2015). Supporting entrepreneurial business success at the base of pyramid through entrepreneurial competencies. Management Decision, 53(6), 1203-1223. 
Rahman, S. A., Amran, A., Ahmad, N. H., \& Taghizadeh, S. K. (2014). GrameenPhone: Creating a win-win at the base of the pyramid in Bangladesh. Global Business \& Organizational Excellence, 33(5), 41-53.

Rahman, M., Hasan, M. R., \& Floyd, D. (2013). Brand orientation as a strategy that influences the adoption of innovation in the bottom of the pyramid market. Strategic Change, 22(3), 225-239.

Ramus, T., \& Vaccaro, A. (2017). Stakeholders matter: How social enterprises address mission drift. Journal of Business Ethics, 143(2), 307-322.

Rashid, A. T., \& Rahman, M. (2009). Making profit to solve development problems: The case of Telenor AS and the village phone programme in Bangladesh. Journal of Marketing Management, 25(9/10), 1049.

Reficco, E., \& Gutiérrez, R. (2016). Organizational ambidexterity and the elusive quest for successful implementation of BoP ventures. Organization \& Environment, 29(4), 461-485.

Reficco, E., \& Márquez, P. (2012). Inclusive networks for building BoP markets. Business \& Society, 51(3), 512-556.

Rivera-Santos, M., \& Rufín, C. (2010). Global village vs. small town: Understanding networks at the Base of the Pyramid. International Business Review, 19(2), 126-139.

Rivera-Santos, M., Rufín, C., \& Kolk, A. (2012). Bridging the institutional divide: Partnerships in subsistence markets. Journal of Business Research, 65(12), 1721-1727.

Sánchez, P., \& Ricart, J. E. (2010). Business model innovation and sources of value creation in low-income markets. European Management Review, 7(3), 138-154.

Santos, N. J., Laczniak, G. R., \& Facca-Miess, T. M. (2015). The "Integrative Justice Model" as transformative justice for base-of-thepyramid marketing. Journal of Business Ethics, 126(4), 697-707.

Schrader, C., Freimann, J., \& Seuring, S. (2012). Business strategy at the base of the pyramid. Business Strategy and the Environment, 21(5), 281.

Scott, L., Dolan, C., Johnstone-Louis, M., Sugden, K., \& Wu, M. (2012). Enterprise and inequality: A study of avon in South Africa. Entrepreneurship Theory and Practice, 36(3), 543-568.

Seelos, C., \& Mair, J. (2005). Social entrepreneurship: Creating new business models to serve the poor. Business Horizons, 48(3), 241-246.

Seelos, C., \& Mair, J. (2007). Profitable business models and market creation in the context of deep poverty: A strategic view. The Academy of Management Perspectives, 21(4), 49-63.

Sen, A. (1999). The possibility of social choice. American Economic Review, 89(3), 349-378

Simanis, E., \& Hart, S. L. (2009). Innovation from the inside out. MIT Sloan Management Review, 50(4), 77.

Sinkovics, N., Sinkovics, R. R., \& Yamin, M. (2014). The role of social value creation in business model formulation at the bottom of the pyramid-implications for MNEs? International Business Review, 23(4), 692-707.

Stephan, U., Patterson, M., Kelly, C., \& Mair, J. (2016). Organizations driving positive social change: A review and an integrative framework of change processes. Journal of Management, 42(5), $1250-1281$.

Tasavori, M., Zaefarian, R., \& Ghauri, P. N. (2015). The creation view of opportunities at the base of the pyramid. Entrepreneurship \& Regional Development, 27(1), 106-126.

Tashman, P., \& Marano, V. (2009). Dynamic capabilities and base of the pyramid business strategies. Journal of Business Ethics, 89, 495-514.

Tate, W. L., \& Bals, L. (2018). Achieving shared triple bottom line (TBL) value creation: toward a social resource-based view (SRBV) of the firm. Journal of Business Ethics, 152(3), 803-826.

Thompson, J. D., \& MacMillan, I. C. (2010). Business models: Creating new markets and societal wealth. Long Range Planning, 43(2), 291-307.

Tranfield, D., Denyer, D., \& Smart, P. (2003). Towards a methodology for developing evidence-informed management knowledge by means of systematic review. British Journal of Management, 14(3), 207-222.

Trevinyo-Rodríguez, R. N., \& Chamiec-Case, L. (2012). Pursuing financial inclusion of family firms at the base of the pyramid (BoP): The case of convenience stores and microenterprises in Nuevo León, Mexico. Journal of Small Business \& Entrepreneurship, 25(2), 231-248.

Vachani, S., \& Smith, N. C. (2008). Socially responsible distribution: Distribution strategies for reaching the Bottom of the Pyramid. California Management Review, 50(2), 52-84.

Valente, M. (2012). Indigenous resource and institutional capital: The role of local context in embedding sustainable community development. Business \& Society, 51(3), 409-449.

Van den Waeyenberg, S., \& Hens, L. (2012). Overcoming institutional distance: Expansion to base-of-the-pyramid markets. Journal of Business Research, 65(12), 1692-1699.

Van den Waeyenberg, S., \& Hens, L. (2008). Crossing the bridge to poverty, with low-cost cars. The Journal of Consumer Marketing, 25(7), 439-445.

Van der Byl, C. A., \& Slawinski, N. (2015). Embracing tensions in corporate sustainability: A review of research from win-wins and trade-offs to paradoxes and beyond. Organization \& Environment, 28(1), 54-79.

Williams, R., \& Hayes, J. (2013). Literature review of seminal papers on 'Shared value.' Unpublished document. Available online at: assets.publishing.service.gov.uk

Yunus, M., Moingeon, B., \& Lehmann-Ortega, L. (2010). Building social business models: Lessons from the Grameen experience. Long Range Planning, 43(2-3), 308-325.

Publisher's Note Springer Nature remains neutral with regard to jurisdictional claims in published maps and institutional affiliations. 